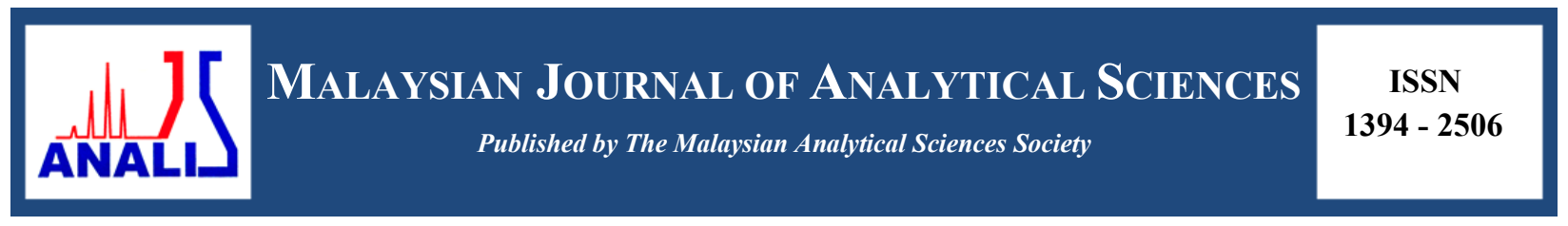

\title{
OLEIC ACID ENHANCEMENT IN USED FRYING PALM OIL VIA ENZYMATIC ACIDOLYSIS
}

\section{(Peningkatan Kandungan Asid Oleik dalam Minyak Sawit Terpakai Melalui Kaedah Asidolisis Enzim)}

\author{
Nor Athirah Zaharudin ${ }^{1}$, Nurul Syafiqah binti Remzi ${ }^{1}$, Roslina Rashid ${ }^{1}$, Siti Marsilawati Mohamed Esivan ${ }^{1}$, \\ Ani Idris ${ }^{1}$, Norasikin Othman ${ }^{2}$ \\ ${ }^{1}$ Bioprocess and Polymer Engineering Department, School of Chemical and Energy, Faculty of Engineering \\ ${ }^{2}$ Chemical Engineering Department, School of Chemical and Energy, Faculty of Engineering \\ Universiti Teknologi Malaysia, 81310 Skudai, Johor, Malaysia \\ *Corresponding author: roslina@cheme.utm.my
}

Received: 16 April 2017; Accepted: 7 March 2018

\begin{abstract}
The extensive amount of used frying palm oil (UFO) generated in Malaysia has caused serious environmental problems. Management of the waste faces a significant challenge especially on choosing the appropriate method by considering the possibilities of contaminating the environment. This study aims to add value to UFO by producing high oleic palm oil. Enzymatic acidolysis using lipase was employed to incorporate oleic acid in the UFO. This study also investigated the effect of enzymatic loading, reaction time and water content on the properties of modified UFO as to find the optimum condition for oleic acid incorporation. Oleic acid incorporation was quantified based on peroxide and iodine values. The optimum conditions for acidolysis process were obtained at enzyme loading of $30 \%(\mathrm{w} / \mathrm{w})$, reaction time of 24 hours, and water content of $2 \%(\mathrm{w} / \mathrm{w})$ with substrate mole ratio of 1:2 (UFO: oleic acid) and temperature of $50{ }^{\circ} \mathrm{C}$. At optimum conditions, the modified used frying palm oil (MUFO) has peroxide and iodine values of $19.00 \pm 0.99 \mathrm{meq} / \mathrm{mg}$ and $31.5 \pm 0.42 \mathrm{mg} / \mathrm{mg}$, respectively. After the acidolysis reaction, oleic acid concentration has increased from $27.00 \pm 0.70 \%(\mathrm{v} / \mathrm{v})$ to $62.34 \pm 1.29 \%(\mathrm{v} / \mathrm{v})$, demonstrating their feasibility as a substrate for structured lipid production.
\end{abstract}

Keywords: enzymatic acidolysis, used frying palm oil, oleic acid, high oleic palm oil, oleic acid incorporation

\begin{abstract}
Abstrak
Lambakan minyak sawit terpakai (UFO) di Malaysia telah menyebabkan banyak masalah alam sekitar yang serius. Pengurusan sisa ini menempuh cabaran besar terutamanya dari espek pemilihan kaedah pelupusan yang mengambil kira kemungkinankemungkinan yang boleh mencemarkan alam sekitar. Kajian ini bertujuan menambah nilai UFO dengan menghasilkan minyak sawit tinggi asid oleik. Asidolsis enzimatik menggunakan lipase telah dijalankan untuk menggabungkan asid oleik ke dalam UFO. Kajian ini juga mengkaji kesan kepekatan enzim, masa tindak balas dan kandungan air pada sifat-sifat minyak sawit terubahsuai (MUFO) untuk mencari keadaan optimum peningkatan asid oleik. Peningkatan asid oleik dinilai berdasarkan nilai peroksida dan nilai iodin. Keadaan optimum untuk proses asidolisis yang diperoleh adalah pada kepekatan enzim 30\% (w/w), masa tindak balas 24 jam dan kandungan air 2\% (w/w) pada nisbah substrat 1:2 (UFO: asid oleik) serta suhu $50{ }^{\circ} \mathrm{C}$. Pada keadaan optimum MUFO mempunyai nilai peroksida $19.00 \pm 0.99 \mathrm{meq} / \mathrm{mg}$ dan nilai iodin $31.5 \pm 0.42 \mathrm{mg} / \mathrm{mg}$. Selepas tindak balas asiolisis enzim, kepekatan asid oleik telah meningkat dari $27.00 \pm 0.70 \%$ (v/v) kepada $62.34 \pm 1.29 \%(\mathrm{v} / \mathrm{v})$, membuktikan UFO mampu menjadi substrat untuk penghasilan lipid berstruktur.
\end{abstract}

Kata kunci: asidolisis enzim, minyak terpakai, asid oleik, minyak sawit tinggi asid oleik, peningkatan asid oleik 


\section{Introduction}

Structured lipids are defined as triacylglycerols (TAG) which have been chemically or enzymatically modified by altering the fatty acids composition and/or positional distribution in the glycerol backbone [1]. Products produced from TAG modification include cocoa butter equivalents, low-caloric fats, human milk substitutes, oil with enhanced essential fatty acids, margarines as well as plastic fats. The use of lipases as catalytic tools to alter fats and oils has attract many researches to produce wide range of structured lipids either for food or non-food purposes that offer excellent chemo-, region-, and stereo- selectivity properties.

The growth in human population has contributed to the extensive amount of used frying oil (UFO) generated and discharged to the environment. A greater quantity of UFO was produced from various sources including households, restaurants, catering establishment, as well as industrial kitchens. In Malaysia, approximately 50,000 tons of UFO was disposed without proper treatments [2]. Sebayang et al. [3] claimed that the total used-frying oil generated from fast food franchises all over Malaysia reached several thousand litres a day. It is believed that the actual amount of used-frying oil generated is far beyond the estimated value. Improper management of UFO will contribute to water pollution, marine life destruction, soil contamination, human health problems, septic and sewerage system failures, increase water and waste management cost and negative effects on the ecology. The availability of used-frying oil in Malaysia could provide a stable and constant feedstock for the demand on structured lipids production.

Production of structured lipid or tailor made fats provides an opportunity for cheap oils and fats to be utilized for the synthesis of high added value products. Utilization of UFO for biodiesel production is well explored. However, the utilization of used-frying oil still lacks of scientific investigation due to limited chemical and physical functionalities. Therefore, enhancement of used-frying oil into high quality oil offers an alternative route to a wide range of applications, thus reducing the environmental effect caused by its disposal problems.

Palm oil and palm olein have moderate contents of oleic acid [4, 5]. Vegetable oils with enhanced oleic acid content receive great attention for the use in a variety of industrial applications [6]. Oleic acid can be incorporated into oils to increase the oleic content of the mother oil, offer desirable properties related to both health benefits and stability characteristics [4]. According to Corbett [7], high oleic canola oil has twice the oxidative stability compared to regular canola oil. Besides stabilizing the oil, high oleic oils are also exploited in the preparation of snack food including potato chips frying as well as spraying to enhance mouth-feel and palatability. Not only restricted for food purposes, high oleic oils have been utilized for non-food applications. Vegetable-based high oleic oil can be further processed via transesterification to produce products such as polyurethane [8]. Ramli et al. [9] indicated that palm oil is among the vegetable source of monounsaturated fatty acids due to the abundant amount of palm oil available in Malaysia as compared to soybean and sunflower oils.

Acidolysis is a reaction where the fatty acyl group is exchanged through a combination of hydrolysis of a donor ester with esterification of released alcohol moiety with other free fatty acids [4]. Hypothetically, this reaction produces the mixtures of triacyglyceride (TAG) and targeted structured TAGs as well as fatty acids. Enzymatic acidolysis offers an easy, specific, fast, and cost friendly method for fatty acids enrichment of oils compared to time, energy and cost consuming of genetic engineering. Utilization of UFO provides an alternative method for cheap oil to be exploited for the production of high value added products where the cost of raw materials is much lower. Raw materials cost and the availability of fresh vegetable oil feedstocks are always major concern. In addition, most of the studies conducted on the enhancement of oil are using fresh cooking oil. The high cost of fresh vegetable oils could increase the total production cost up to $1.5 \%$ [10]. However, the price of UFO is 2 to 3 times cheaper than fresh vegetable oil. Hence, the production cost can be significantly reduced.

Rafael and Roberto [11] have emphasized the advantages of acidolysis process including the high positional selectivity and specificity, low cost and fewer side products, initiated by the inevitable existence of acyl migration which can be minimized by controlling the reaction conditions such as enzyme load, water content, substrate ratio, reaction temperature, and reaction time. Therefore, enzymatic acidolysis has been preferred as a suitable method to enrich vegetable oils with regard to the modification of oils rich in high value polyunsaturated fatty acids such as linoleic, oleic, arachidonic, eicosapentaenoic, and docosahexaenoic acids. The use of lipase for fats and oils 
enhancement offers some benefits over conventional organic catalysts; increases the product purity, operates at mild reaction conditions, high substrate selectivity, and less or no unwanted side products [12]. Candida rugosa lipase is a non-specific lipase which catalyzes lipid at random position and successfully applied on the synthesis of oil hydrolysis, biodiesel, fatty acid ester, wax ester as well as monoesters and diesters [13, 14].

In this present study, effects of enzymatic loading, reaction time and water content on oleic acid incorporation degree were investigated. Oleic acid incorporation in UFO was quantified based on peroxide and iodine values. Oleic acid concentration in MUFO, fresh frying oil (FFO) and used frying oil (UFO) were compared.

\section{Materials}

\section{Materials and Methods}

Used frying palm oil (UFO) was obtained from the university cafeteria. Lipase from Candida rugosa was used as the catalysts and was immobilized on immobead 150. Pure oleic acid was purchased from Qrec Sdn. Bhd., Malaysia. Solvents including $n$-hexane, cyclohexane, acetone, and acetonitrile were purchased from a local supplier as well as other chemicals (phenolphthalein, sodium phosphate). All chemicals are analytical grade and were used without further purification.

\section{Pre-treatment}

Sample pre-treatment procedures were conducted based on the method proposed by Przybylski et al. [15], Pazouki et al. [16], and Hasnisa and Jumat [17]. UFO contains lot of impurities caused by continuous cooking and oxidation process. Therefore, pre-treatment was conducted to eliminate the indiscerptible impurities. Firstly, $50 \mathrm{ml}$ of UFO was filtered by applying a reduced pressure system using a Whatman 42 filter paper [16]. The filtered UFO was stirred and heated to $100{ }^{\circ} \mathrm{C}$ for 15 minutes. Heating process was engaged as to eliminate excess water. Then, peroxide, iodine, and acid values were recorded.

\section{Determination of peroxide value}

Firstly, $10 \mathrm{ml}$ of UFO and $50 \mathrm{ml}$ of glacial acetic acid-isooctane mixture $(3: 2 \mathrm{v} / \mathrm{v})$ were added into a $250 \mathrm{ml}$ conical flask and stirred at low speed. Then, $1 \mathrm{ml}$ of potassium iodide was added and continuously stirred at low speed for 1 minute. $100 \mathrm{ml}$ of distilled water and $0.1 \mathrm{~g}$ thyodene indicator were added into the mixture. The mixture was mixed vigorously and immediately titrated with $0.1 \mathrm{~N}$ sodium thiosulfate (colour indication: from purple to a slight yellow or colourless endpoint). The blank determination was determined under the same condition. The peroxide value was calculated based on formula presented in equation 1 [18]:

$$
P O V=\frac{\left(V_{1}-V_{0}\right) \times N \times 1000 \times T}{V_{S} \times 2}
$$

where, $P O V$ is the peroxide value of UFO ( $\mathrm{mmol} / \mathrm{L}), V_{l}$ is the sodium thiosulfate volume needed to neutralize UFO $(\mathrm{ml}), V_{0}$ is the sodium thiosulfate volume needed to neutralize the blank solution $(\mathrm{ml}), N$ is the sodium thiosulfate normality $(0.1 \mathrm{~N}), \mathrm{T}$ is titre of sodium thiosulfate, and $V_{S}$ is the volume portion of substance $(\mathrm{ml})$.

\section{Determination of iodine value}

Approximately $0.1 \mathrm{~g}$ of UFO and $20 \mathrm{ml}$ of carbon tetrachloride $\left(\mathrm{CCl}_{3}\right)$ were inserted and sealed in to $250 \mathrm{ml}$ conical flask. The mixture was dissolved by applying high agitation speed. Then, $25 \mathrm{ml}$ of Hanus solution was added and stirred for one minute. The mixture was sealed and leaved in a dark room at $20^{\circ} \mathrm{C}$ for 30 minutes. After that, $10 \mathrm{ml}$ of $15 \%$ potassium iodide and $100 \mathrm{ml}$ of water were added, sealed and shaken for 30 seconds. Lastly, the sample mixture was titrated with $0.1 \mathrm{~N}$ sodium thiosulfate in order to obtain the iodine value. The formula for calculating the iodine value is presented by equation 2 [19]:

$$
I V=\frac{\left(V_{1}-V_{0}\right) \times N \times 12.69}{W}
$$

where; $I V$ is the iodine value of UFO $\left(\mathrm{I}_{2} / \mathrm{g}\right), V_{l}$ is the sodium thiosulfate volume needed to neutralize UFO $(\mathrm{ml}), V_{0}$ is the sodium thiosulfate volume needed to neutralize the blank solution $(\mathrm{ml}), N$ is the sodium thiosulfate normality $(0.1 \mathrm{~N})$, and $W$ is the weight of UFO $(\mathrm{g})$. 


\section{Determination of acid value}

The acid value was determined by inserting $100 \mathrm{ml}$ of neutralized ethanol-toluene $(1: 1 \mathrm{v} / \mathrm{v})$ mixture and $4 \mathrm{~g}$ of treated UFO into a round bottom flask. The mixture was titrated with standard potassium hydroxide $(\mathrm{KOH})$ in the presence of phenolphthalein (end point: pink colour). The acid value was calculated using the formula shown in equation 3 [19]:

$$
A V=\frac{M W \times N \times V_{1}}{W}
$$

where, $A V$ is the acid value of UFO (mg KOH$/ \mathrm{g}$ ), $M W$ is the molecular weight of $\mathrm{KOH}(56.1 \mathrm{~g} / \mathrm{mol}), V_{l}$ is $\mathrm{KOH}$ volume used to neutralize the sample solution $(\mathrm{ml}), N$ is the $\mathrm{KOH}$ normality $(1.0 \mathrm{~N})$, and $W$ is the weight of UFO (g).

\section{Acidolysis of UFO}

Acidolysis of UFO with oleic acid and determination on effect of operating conditions upon oleic 1acid incorporation degree were conducted according to the method by Zou et al. [20], Siew and Saw [21], and Has nisa and Jumat [17]. A mixture of treated UFO and oleic acid (1:2 mol/mol) were added to $n$-hexane $(2 \mathrm{ml})$ followed by water $(1 \% \mathrm{w} / \mathrm{w})$ and lipase $(10 \% \mathrm{w} / \mathrm{w})$. The mixture was incubated at temperature of $50{ }^{\circ} \mathrm{C}$, agitation speed of 250 rpm for 24 hours. The sample was titrated as to determine the peroxide and iodine value. Effect of operating conditions was determined by varying enzyme load $(0-30 \% \mathrm{w} / \mathrm{w})$, reaction time $(0-36$ hours $)$, and water content $(0-$ $3 \% \mathrm{w} / \mathrm{w})$. Enzymatic acidolysis using fresh frying palm oil was also conducted using the same optimum values gained in the acidolysis of UFO.

\section{Separation of triacylglycerols}

The separation of triacylglycerol was carried out based on method of Hasnisa and Jumat [17] and Senanayake and Shahidi [22]. Lipase was filtered from the reacted sample. The filtered sample was added to a mixture of acetone/ethanol $(1: 1 \mathrm{v} / \mathrm{v})$ in $50 \mathrm{ml}$ conical flask. Phenolphthalein indicator was added to the reaction mixture and titrated with $0.5 \mathrm{~N} \mathrm{NaOH}$ (end point: pink). The mixture was added with $25 \mathrm{ml}$ of hexane and transferred to a separatory funnel. The lower layer was separated and discarded. The upper layer (hexane and TAG) was passed through a bed of anhydrous sodium sulphate. The TAG fractionation was completed by hexane removal at $45{ }^{\circ} \mathrm{C}$ using a rotary evaporator (IKA RV 8) for 15 minutes.

\section{GC Analysis}

Determination of oleic acid concentration was conducted based on the method done by Hasnisa and Jumat [17]. Oleic acid content in the sample was determined by gas chromatography with flame ionization detector (Perkin Elmer XL-GC). One $\mathrm{mL}$ of the sample was diluted in $40 \mathrm{ml}$ of isopropanol and filtered using a microfilter of 0.45 micropores before injecting into the GC-FID column. Then, $1 \mu \mathrm{l}$ of diluted sample was injected into the GC-FID column at a flow rate of $1 \mu \mathrm{l} / \mathrm{min}$. The TAG peaks were identified according to reference standards and were compared with fresh-frying oil, which was used as a benchmark. Quantification of oleic acid content was done based on the percentage of area.

\section{Properties of fresh frying oil and used frying oil}

Results and Discussion

Peroxide value (PV) indicates the quality of oil [9]. Peroxide value measures the oxidative and rancidity of the oil. Generally peroxide value increases with frying time [23]. The result shows that PV for UFO $(38.8 \pm 1.56 \mathrm{meq} / \mathrm{kg})$ is higher than FFO $(3.8 \pm 1.27 \mathrm{meq} / \mathrm{kg})$. UFO became rancid due to oxidation. Fan et al. [24] reported that the peroxide value of palm olein after 5 days of frying has increased from 3.40 to $34.55 \mathrm{meq} / \mathrm{kg}$. The peroxide concentration, usually expressed as PV, is measured by oxidation or rancidity in its early stages and should be not more than 10 (milliequivalents peroxide $/ 1000 \mathrm{~g}$ sample) in cooking oil. It was observed that the measured iodine value (IV) value for FFO and UFO are $35.15 \pm 1.06 \mathrm{mg} / \mathrm{mg}$ and $33.2 \pm 1.41 \mathrm{mg} / \mathrm{mg}$ respectively. Lower IV indicates low degree of unsaturation which means higher oxidation rate. The result shows that UFO has similar stability as compared to FFO. Slightly lower unsaturation in UFO is due to oxidation and heating process. Talpur et al. [25] reported the decreasing trend of iodine value is caused by the increase in frying cycle. Iodine value 
reflects the degree of unsaturation of the oil. As the oil undergoes continuous heating, double bond raptures will lead to the increase in saturation of fatty acids [26]. In other words, high iodine value is preferred. Acid number or acid value (AV) of an oil is corresponds to the ester amount present in the oil which indicates the quantity of free fatty acids. It was observed that, measured AV for FFO and UFO are $3.9 \pm 0.99 \mathrm{mg} \mathrm{KOH} / \mathrm{g}$ and $35.06 \pm 1.47 \mathrm{mg}$ $\mathrm{KOH} / \mathrm{g}$, respectively. UFO has a higher AV compared to fresh-frying oil. Higher AV for UFO compared to FFO is due to the increase in fatty acids content during frying process [27]. Aladedunye and Przybyliski [28] stated that the change in free fatty acids content is due to the double bond rapture during the frying process.

\section{Effect of enzyme load}

Increase in enzyme load will contribute towards the positive effect on fatty acids incorporation into targeted the TAG [17]. Commonly, the incorporation degree increases with enzyme loads until it reaches the optimum load. However further increase afterwards has no significant effect towards the incorporation degree. Zou et al. [20] indicated this trend is possibly due to the saturation of enzyme at the interface and aqueous phase. Hasnisa and Jumat [17] specified that at higher enzyme load the decrease in incorporation degree is significant due to insufficient amount of water in the reaction mixture. As the amount of enzyme increased the amount of water remains constant.

Result shows that the peroxide value decreased as the enzyme load increased. A low amount of peroxide value indicates a high degree of unsaturation that causes autoxidation (oxidative rancidity) [29]. Kaleem et al [30] stated that the double bond in fats and oils are responsible for autoxidation. Hence, oils with higher degree of unsaturation are extremely prone to autoxidation. However a different trend was observed in iodine value. The enzyme loads increased with iodine value. High amount of iodine value and low peroxide value were found at $30 \%$ of enzyme load. This indicates that more $\mathrm{C}=\mathrm{C}$ bonds are present in the fats and oils. The increase in iodine value shows that oleic acid has successfully incorporated in triacylglycerol (TAG) [17]. Oleic acid in palm oil is predominantly located at sn-2 position in TAG [31]. Sufficient amount of enzyme promotes the incorporation of oleic acid at $s n-1,3$ positions in TAG. In addition, acyl migration from $s n-2$ position of TAG should be considered as Candida rugosa lipase which is a non-stereoselective lipase and randomly catalyzed oleic acid at any position of TAG. Enzyme load of 30\% (w/w) was selected as the optimum enzyme load with the highest iodine value of $16.40 \pm 2.26$ $\mathrm{mg} / \mathrm{mg}$ and lower peroxide value of $6.40 \pm 2.40 \mathrm{meq} / \mathrm{mg}$. Effects of enzyme load towards peroxide and iodine values are presented in Figure 1.

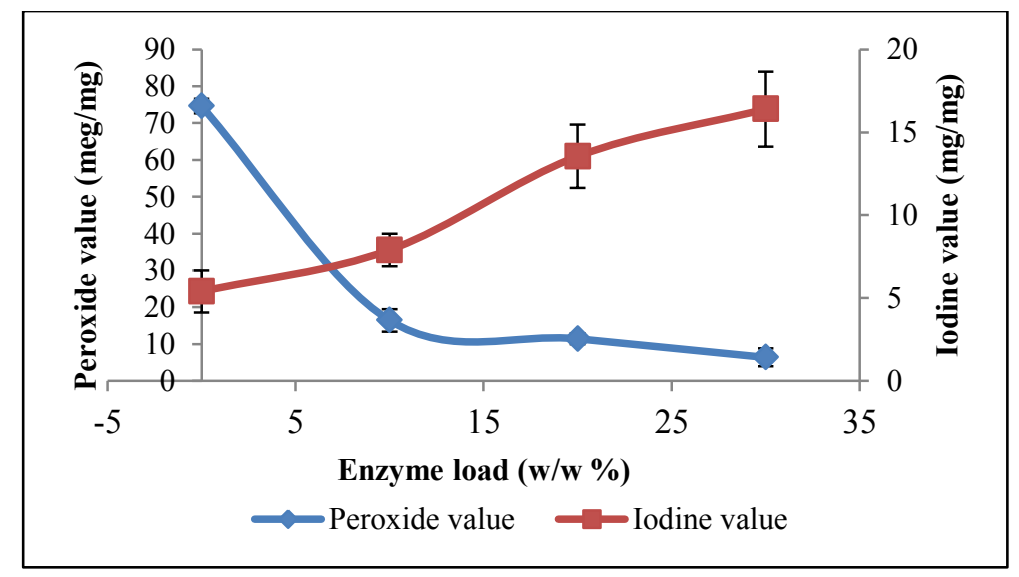

Figure 1. Effect of enzyme load on peroxide and iodine values. Conditions: substrate mol ratio (UFO: oleic acid) 2:1, $2 \mathrm{ml} n$-hexane, $1 \%(\mathrm{w} / \mathrm{w})$ water, at constant temperature of $50{ }^{\circ} \mathrm{C}$, and $250 \mathrm{rpm}$ agitation speed for 24 hours

\section{Effect of reaction time}

Savaghebi et al. [32] indicated the effect of reaction time is crucial in order to determine the optimal rate of reaction as well as reduce the process cost. The incorporation degree increases with the reaction time [33]. In addition a 
longer reaction time will result in the increase of acyl group migration especially in laboratory-scale continuous reactor [11]. A study conducted by Hasnisa and Jumat [17] showed incorporation of PUFA increased with reaction time, but decreased after 48 hours. Zhao et al. [34] obtained the highest incorporation of capric acid at 24 hours. A similar result was also obtained by Hamam and Shahidi [35].

The peroxide value of UFO is increased from 0 to 12 hour and slightly decreased until 36 hours. The results also showed that iodine value increased with reaction time. The increase in iodine value can be explained by the successful incorporation of oleic acid. However, the peroxide value is slightly decreased at reaction time of 24 hours. The decrease of peroxide value is due to the oxidation process during storage. At 24 hours, the iodine value shows the highest iodine value which indicated the highest amount of unsaturated fatty acid. Therefore, the optimum time for UFO acidolysis reaction is 24 hours with the highest iodine value $(12.00 \pm 1.27 \mathrm{mg} / \mathrm{mg})$ and low peroxide $(10.70 \pm 2.55 \mathrm{meq} / \mathrm{mg})$ value. Effect of reaction time towards peroxide and iodine values is presented in Figure 2 .

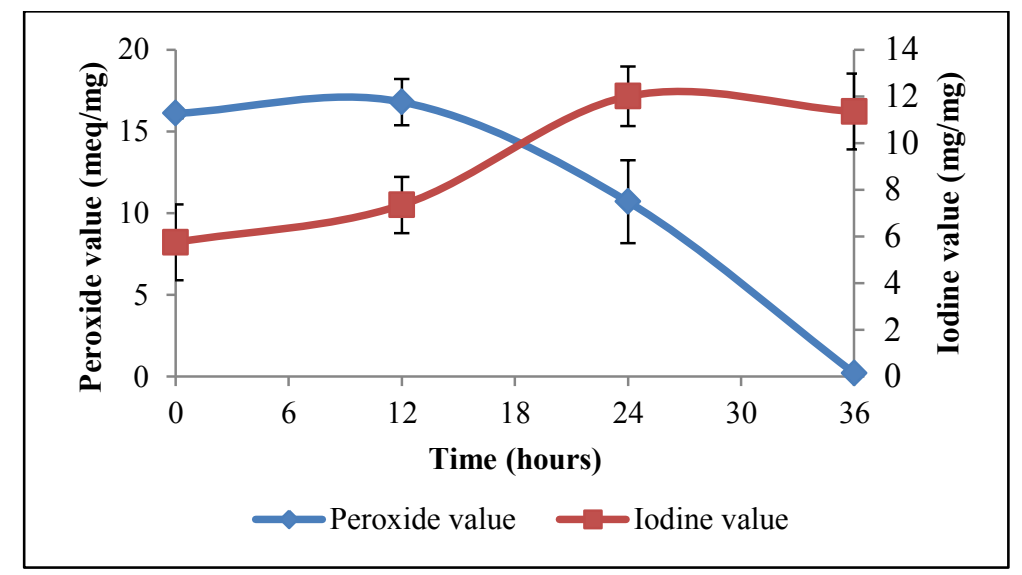

Figure 2. Effect of reaction time on peroxide and iodine values. Conditions: substrate mole ratio (UFO: oleic acid) $2: 1,30 \%(\mathrm{w} / \mathrm{w})$ enzyme load, $2 \mathrm{ml} n$-hexane, $1 \%(\mathrm{w} / \mathrm{w})$ water, $50{ }^{\circ} \mathrm{C}$, and $250 \mathrm{rpm}$

\section{Effect of water content}

Lipase is generally activated by a small amount of water where it is vital for a first breaking of TAG [11]. Hence, water content in any quantity cannot be neglected. An optimum level of water in the reaction is essential to maintain the enzyme activity [17]. However, too much water will make the lipase unstable and promotes adverse impact on lipase activity, leading to an increase in amount of by-products. Conversely, a low water content will lead to the decrease in enzyme activity. Senanayake and Shahidi [22] reported that inadequate amount of added water may initiate the enzyme to be inactive as water is required to maintain the three-dimensional structure of enzyme.

An increase in water content was expected to have a positive effect in iodine value and negative effect in peroxide value. Both iodine and peroxide values indicated that as the water content increased from $0-2 \%$, the iodine value is increased accordingly while the peroxide value decreased from $0-3 \%$. The results showed that the higher the iodine value the higher the incorporation of oleic acid in UFO. However, at 3\% of water content, there was a slight decrease of iodine value followed by the decrease of oleic acid incorporation in UFO. Excessive amount of water however resulted in poor incorporation of oleic acid in UFO. High amount of water will promote hydrolysis in the oil instead of acidolysis [22]. The optimum water content for UFO acidolysis was obtained at $2 \%(\mathrm{w} / \mathrm{w})$ water content with $31.50 \pm 0.42 \mathrm{mg} / \mathrm{mg}$ iodine value and $19.00 \pm 0.99 \mathrm{meq} / \mathrm{mg}$ peroxide value. Effect of water content towards peroxide and iodine values is presented in Figure 3. 


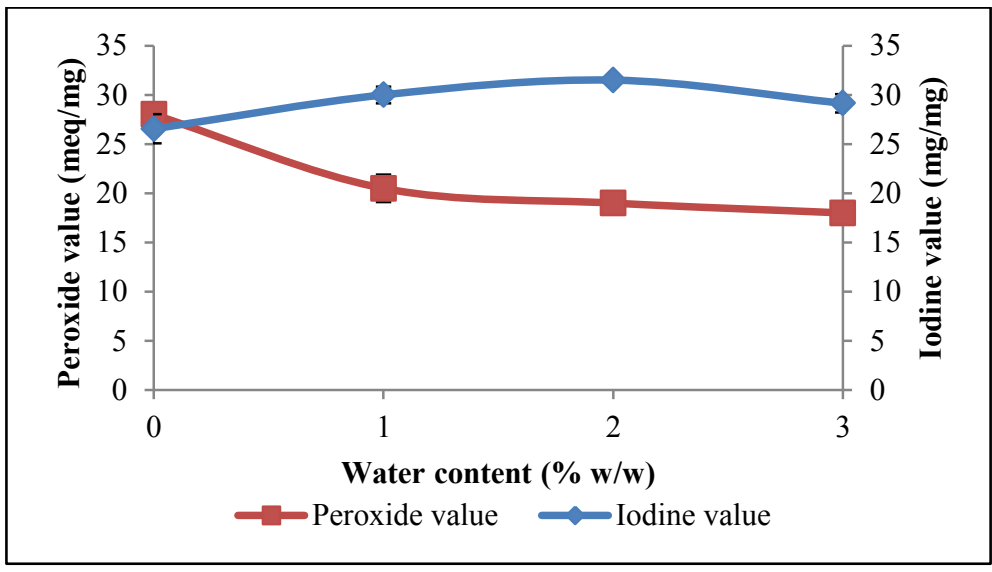

Figure 3. Effect of water content on peroxide and iodine values. Conditions: substrate mole ratio (UFO: oleic acid) $2: 1,30 \%(\mathrm{w} / \mathrm{w})$ enzyme load, $2 \mathrm{ml} n$-hexane, 24 hours, $50{ }^{\circ} \mathrm{C}$, and $250 \mathrm{rpm}$

\section{GC analysis: Oleic acid content}

Acidolysis of fresh frying oil (FFO) shows an increase in oleic acid concentration from $21.10 \pm 1.40 \%(\mathrm{v} / \mathrm{v})$ to $36.56 \pm 1.29 \%(\mathrm{v} / \mathrm{v})$. However, acidolysis of UFO shows a higher incorporation of oleic acid. The oleic acid content has increased from $27.00 \pm 0.70 \%(\mathrm{v} / \mathrm{v})$ to $62.34 \pm 1.29 \%(\mathrm{v} / \mathrm{v})$. The increase of the oleic acid concentration in both UFO and FFO is shown in Figure 4. Enzymes can improve the incorporation of fatty acids [11]. It shows that the enzyme load affects the amount of fatty acid concentration before and after acidolysis. Increase of enzyme load accelerated the reaction rate and improved the incorporation of acyl donors under given conditions [36]. Páez et al. [37] stated that the enzyme requires a certain level of water in the reaction medium to maintain a layer of water molecules around the enzyme and to maintain the enzyme activity for initiating the reaction. It showed that the enzyme plays an important role to lead off the reaction in order to achieve a high content of fatty acid.

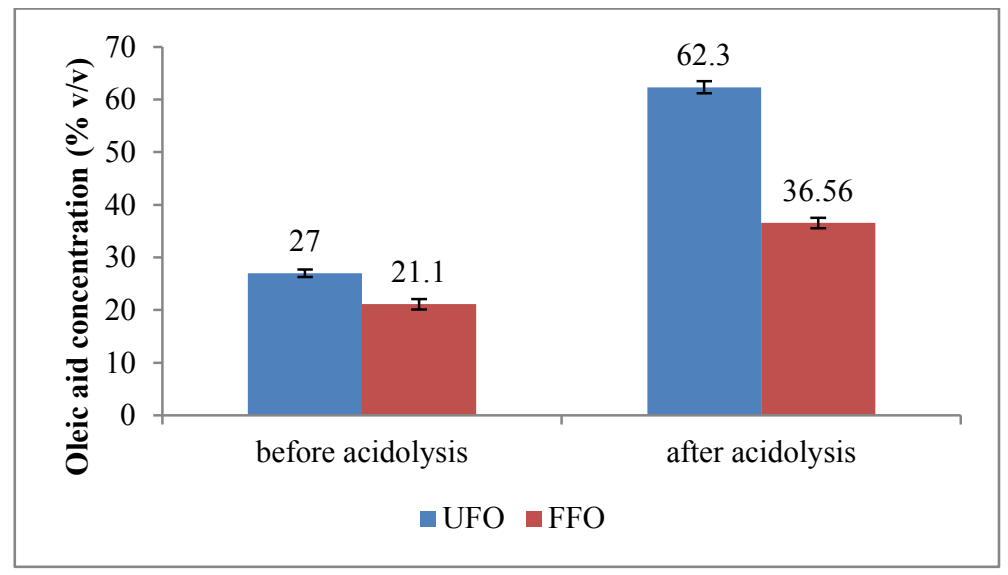

Figure 4. Oleic acid concentrations before and after acidolysis

\section{Conclusion}

In this study, UFO has a higher peroxide and acid values with lower iodine value when compared to FFO. The optimum conditions for the acidolysis process were obtained at enzyme loading of $30 \%(\mathrm{w} / \mathrm{w})$, reaction time of 24 hours and water content of $2 \%(\mathrm{w} / \mathrm{w})$. At the optimum conditions, the modified UFO has a peroxide value of $19 \pm$ $0.99 \mathrm{meq} / \mathrm{mg}$ and iodine value of $31.5 \pm 0.42 \mathrm{mg} / \mathrm{mg}$. The modified UFO has higher oleic acid content, $62.34 \pm$ 
$1.29 \%(\mathrm{v} / \mathrm{v})$ compared to UFO before acidolysis reaction, $27.00 \pm 0.70 \%(\mathrm{v} / \mathrm{v})$. It can be concluded that oleic acid has been successfully incorporated into UFO.

\section{Acknowledgement}

This research is fully supported by RUG grant, Q.J130000.2546.12H37. The authors fully acknowledged the Ministry of Higher Education (MOHE) and Universiti Teknologi Malaysia for the approved fund which makes this important research viable and effective

\section{References}

1. Esteban, L., Jiménez, M. J., Hita, E., González, P. A., Martín, L. and Robles, A. (2011). Production of structured triacylglycerols rich in palmitic acid at sn-2 position and oleic acid at sn-1,3 positions as human milk fat substitutes by enzymatic acidolysis. Biochemical Engineering Journal, 54(1): 62-69.

2. Nurdin, S., Yunus, R. M., Nour, A. H., Gimbun, J., Azman, N. A. N. and Sivaguru, M. V. (2016). Restoration of waste cooking oil (WCO) using alkaline hydrolysis technique (ALHT) for future biodetergent. ARPN Journal of Engineering and Applied Sciences, 11: 6405-6410.

3. Sebayang, D., Agustian, E. and Praptijanto, A. (2010). Transesterification of biodiesel from waste cooking oil using ultrasonic technique. International Conference on Environment. 13-15 December. Penang, Malaysia: pp. $1-9$.

4. Ferreira-Dias, S., Sandoval, G., Plou, F. and Valero, F. (2013). The potential use of lipases in the production of fatty acid derivatives for the food and nutraceutical industries. Journal of Biotechnology, 16(3): 1-36.

5. Xu, X. (2000). Production of specific structured-triacylglycerols by lipase-catalysed reactions: A review. European Journal of Lipid Science and Technology, 102(4): 287-303.

6. Kinney, A. J. and Clemente, T. (2005). Modifying soybean oil for enhanced performance in biodiesel blends. Fuel Processing Technology, 86(10): 1137-1147.

7. Corbett, P. (2003). It is time for an oil change: Opportunities for high-oleic vegetables oils. Inform, 14(8): 480481.

8. Arniza, M. Z., Seng, S. H., Idris, Z., Shoot, K. Y., Abu Hassan, H, Din, A. K. and Yuen, M. C. (2015). Synthesis of transesterified palm olein-based polyol and rigid polyurethanes from this polyol. Journal of American Oil Chemistry Society, 92(2): 243-255.

9. Ramli, M. R., Siew W. L., Cheah, K. Y., Idris, N. A. and Mat Sahri, M. (2008). Physico-chemical properties and performance of high oleic and palm-based shortenings. Journal of Oleo Science, 57(11): 605-612.

10. Phan, A. N. and Phan, T. M. (2008). Biodiesel production from waste cooking oils. Fuel, 87: 3490-3496.

11. Rafael, C. R. and Roberto, F. L. (2010). Lipase from Rhizomucor miehei as a biocatalyst in fats and oils modifications. Journal of Molecular Catalysis B-Enzymatic, 66(1-2): 15-32.

12. Yigitoglu, M. and Temocin, Z. (2010). Immobilization of C. rugosa lipase on glutaraldehyde-activated polyester fiber and its application for hydrolysis of some vegetable oils. Journal of Molecular Catalysis B: Enzymatic, 66(1-2): 130-135.

13. Zhang, X., Niea,K., Zheng, Y., Wang,F., Deng, L. and Tan, T. (2016). Lipase Candida Sp. 99-125Coupled With-Cyclodextrin as Additive Synthesized the Human Milk Fat Substitutes. Journal of Molecular Catalysis B: Enzymatic, 125: 1-5.

14. BezbradicA, D., Karalazi, I., Ognjanovi, N., Mijin, D., Siler-Marinkovi, S. and Knezevic, Z. (2006). Studies on specificity of candida rugosa lipase catalyzed esterification reaction in organic media.

Journal of Serbian Chemical Society, 71(1): 31-41.

15. Przybylski, R., Gruczynska, E. and Aladedunye, F. (2013). Performance of regular and modified canola and soybean oils in rotational frying. Journal of American Oil Chemists' Society, 90: 1271-1280.

16. Pazouki, M., Zamani, F., Zamzamian, A. H., Fahar, M. and Najafpour, G. (2010). Esterification of free fatty acids by Rhizopus oryzae as cell-catalysed from used cooking oil for biodiesel production. World Applied Sciences Journal, 8(6): 719-724.

17. Hasnisa, H. and Jumat, S. (2012). Enzymatic acidolysis of palm olein with PUFA to improve linoleic and $\alpha$ linolenic acids ratio. Journal of Tropical Agriculture and Food Science, 40(1): 71-79.

18. IFRA. (2011). Analytical Method: Determination of the Peroxide Value. Access online www.ifraorg.org/view_document.aspx?docId=22291. 
19. AOCS. (1989). Official methods and recommended practices of the American oil chemists' society. Ca 5a-40, Cd 1b-87 and Cd 8-53.4. Champaign IL, American Oil Chemists' Society.

20. Zou, X. G., Hu, J. N., Zhao, M. L., Zhu, X. M., Li, H. Y., Liu, X. R., Liu, R. and Deng, Z. Y. (2014). Lipozyme RM IM-catalysed acidolysis of cinnamomum camphora seed oil with oleic acid to produce human milk fat substitutes enriched in medium-chain fatty acids. Journal of Agricultural and Food Chemistry, 62(43): 10594 10603.

21. Siew, W. L. and Saw, M. H. (2009). High oleic enhancement of palm olein via enzymatic interesterification. Journal of Oleo Science, 58(11): 549-555.

22. Senanayake, S. P. J. and Shahidi, F. (2002). Structured lipids via lipase-catalysed incorporation of eicosapentaenoic acid into borage (Borago officinalis L.) and evening primrose (Oenothera biennis L.) oils. Journal of Agricultural and Food Chemistry, 50(3): 477-483.

23. Karakaya, S. and Simsek, S. (2011). Changes in total polar compounds, peroxide value, total phenols, and antioxidant activity of various oils used in deep fat frying. Journal of American Oil Chemists' Society, 88(9): 1361-1366.

24. Fan, H. Y., Sharifudin, M. S., Hasmadi, M. and Chew, H. M. (2013). Frying stability of rice bran oil and palm olein. International Food Research Journal, 20(1): 403-407.

25. Talpur, M. Y., Sherazi, S. T. H., Mahesar, S. A. and Kandhro, A. A. (2009). Effects of chicken frying on soybean, sunflower, and canola oils. Pakistan Journal of Analytical and Environmental Chemistry, 10(1-2): 5966.

26. Kulkarni, M. G. and Dalai, A. K. (2006). Waste cooking oil-an economical source for biodiesel: A review. Indian Journal of Chemical Engineering, 45(9): 2901-2913.

27. Cvengros, J. and Cvengrosova, Z. (2004). Used frying oils and fats and their utilization in the production of methyl esters of higher fatty acids. Biomass and Bioenergy, 27(2): 173-181.

28. Aladedunye F. A. and Przybylski, R. (2009). Protecting oil during frying: A comparative study. European Journal of Lipid Science and Technology, 111(9): 893-901.

29. Majidi, M. I. H. A. L and Bader, A. T. (2015). Sciences physicochemical characteristics of some imported edible vegetable oils in Iraq. Research Journal of Pharmaceutical, Biological and Chemical, 6(5): 488-494.

30. Kaleem, A., Aziz, S., Iqtedar, M., Abdullah, R., Aftab, M., Rashid, F., Shakoori, F. R. and Naz, S. (2015). Investigating changes and effect of peroxide values in cooking oils subject to light and heat. FUUAST Journal of Biology, 5(2): 191-196.

31. Choo, Y. M. and Nesaretnam, K. (2014). Research advancement in palm oil nutrition. European Journal of Lipid Scientific Technology, 116(10): 1301-1315.

32. Savaghebi, D., Safari, M., Rezaei, K., Ashtari, P. and Farmani, J. (2012). Structured lipids produced through lipase-catalysed acidolysis of canola oil. Journal of Agricultural Science Technology, 14(6): 1297-1310.

33. Kocak, D., Keskin, H., Fadiloglu, S., Kowalski, B. and Gogus, F. (2011). Characterization of terebinth fruit oil and optimization of acidolysis reaction with caprylic and stearic acids. Journal of American Oil Chemists' Society, 88(10): 1531-1538.

34. Zhao, H., Lu, Z., Bie, X., Lu, F. and Liu, Z. (2007). Lipase catalysed acidolysis of lard with capric acid in organic solvent. Journal of Food Engineering, 78(1): 41-46.

35. Hamam, F. and Shahidi, F. (2004). Enzymatic acidolysis of an arachidonic acid single-cell oil with capric acid. Journal of the American Oil Chemists' Society, 81(9): 887-892.

36. Çiftçi, O.N., Fadiloğlu, S., Kowalski, B. and Göğüş, F. (2008). Synthesis of cocoa butter triacylglycerols using a model acidolysis system. Grasas y Aceites, 59(4): 316-320.

37. Páez, B. C., Medina, A. R., Rubio, F. C., Morenoa, P. G. and Grima, E. M. (2003). Modelling the effect of free water on enzyme activity in immobilized lipase-catalysed reactions in organic solvents. Enzyme and Microbial Technology, 33(6): 845-853. 